\title{
The Lithium Ion: A Foundation for Psychopharmacological Specificity
}

\author{
Jair C. Soares, M.D., and Samuel Gershon, M.D.
}

The idea of lithium's specificity for bipolar disorder was proposed in Cade's original work in 1949. Since then, many controlled studies have been performed, examining lithium for treatment of bipolar disorder and other psychiatric conditions. This review was undertaken to determine if the suggestion of lithium's specificity has support in the controlled studies conducted after Cade's initial proposal. Studies were selected in a Medline search, dating back to 1966 and also identified from the bibliography of some of these papers. The controlled trials with lithium for the treatment of mania and bipolar depression, unipolar depression, schizophrenia, and schizoaffective disorder were reviewed. The published studies with lithium in other neuropsychiatric conditions were also considered. Additionally, we reviewed literature on other therapeutic agents proposed for bipolar disorder, looking at their comparative effectiveness to lithium. The data analyzed give strong support for lithium's being most effective in bipolar disorder, with minimal or no therapeutic effects in other neuropsychiatric disorders. The neurochemical underpinnings of this specificity are being investigated, without conclusive findings to date. The study of this paradigm of specificity in neuropsychopharmacology research may lead to meaningful contributions to understanding the pathophysiology of bipolar disorder and may help to develop newer treatments for this condition.

[Neuropsychopharmacology 19:167-182, 1998] (C) 1998 American College of Neuropsychopharmacology. Published by Elsevier Science Inc.
KEY WORDS: Lithium; Psychopharmacology; Therapeutics; Bipolar disorder; Specificity

The effect on patients with pure psychotic excitement-that is, true manic attacks-is so specific that it inevitably leads to speculations as to the possible aetiological significance of a deficiency in the body of lithium ions in the genesis of this disorder. (Cade 1949)

The idea of lithium's being a specific treatment for bipolar disorder started with Cade's original report (Cade 1949). Based on his observations that lithium had a

From the Department of Psychiatry, Western Psychiatric Institute and Clinic, University of Pittsburgh School of Medicine, Pittsburgh, Pennsylvania, USA.

Address correspondence to: Samuel Gershon, M.D., Western Psychiatric Institute and Clinic, University of Pittsburgh School of Medicine, 3811 O'Hara Street, Pittsburgh, PA, 15213, USA.

Received February 23, 1998; accepted February 23, 1998. calming effect in guinea pigs, the Australian psychiatrist administered lithium to 10 manic patients and found remarkable benefits in all of them. In three of six patients with dementia precox, there was only a quieting effect, and in the other three, no effects. In three chronic depressive psychotic patients, there was no effect at all. Based on this apparent specificity, Cade suggested that a deficiency in the lithium ion in the organism could be related to the pathogenesis of the disorder. In 1951, Noack and Trautner reported the results of lithium treatment of 100 patients with various mental disorders, and out of 30 manic patients, only one did not improve, giving further support to the idea of specificity in bipolar disorder. Subsequently, Gershon and Trautner (1956) used lithium as an alternative for the maintenance treatment of patients with "shock-dependency," in reference to patients who quickly relapsed after responding to electroconvulsive therapy (ECT), with significant improvement. In this small series, the 
patients who improved had symptoms of bipolar disorder. Gershon and Yuwiler (1960) suggested that lithium had little or no effect in a variety of psychiatric disorders, including schizophrenia, epilepsy, premenstrual tension, and sociopathy, and it was highly efficacious in the treatment of manic patients. Confirming what had been originally proposed by Cade, they suggested that lithium was a specific treatment for this condition. Schou (1963) also supported the notion that lithium had specificity of its actions in the treatment of manicdepression.

After it was introduced into clinical use, lithium was used for a variety of conditions, ranging from pure bipolar disorder to atypical forms, schizoaffective disorder, treatment refractory schizophrenia, impulse control disorder, substance abuse, and different forms of aggressiveness (Schou 1979). It has shown mild benefits in some of these conditions, but it was most effective in typical forms of bipolar disorder, and, indeed, has had a major impact on the treatment of this disorder (Solomon et al. 1995).

It has been debated over the years whether lithium's actions are symptom specific rather than disorder specific (Gershon 1970; Tupin 1972; Miller and Libman 1979; Braden et al. 1982; Delve and Letemendia 1982). Some authors suggested that this apparent specificity of the lithium ion acts not only in bipolar disorder, but also in conditions with episodic course and aggression (Tupin 1972); others have proposed that psychomotor acceleration and periodicity, regardless of the primary diagnosis, confers lithium responsiveness (Miller and Libman 1979). Some of these authors supported the idea of specificity for the disorder, and defended the notion that the few lithium-responsive patients in other diagnostic categories would be atypical forms of bipolar disorder.

In view of the accumulating literature over past 30 years on the comparative effectiveness of lithium in different psychiatric conditions, it seems timely to reexamine the hypothesis of lithium's specificity for bipolar disorder. This paper reviews the studies with lithium in various psychiatric conditions to examine the claim of specificity in the treatment of bipolar disorder. We also investigate the studies of other treatments for bipolar disorder to examine their comparative effectiveness to lithium.

\section{CLINICAL TRIALS OF LITHIUM}

\section{Bipolar Mania}

Lithium has been shown to be a highly effective treatment for mania. Although response rates have varied, they have usually been around 70 or $80 \%$, after a delay of about 1 to 2 weeks for onset of the therapeutic effects
(Prien and Potter 1990; Price and Henninger 1994; Calabrese et al. 1995). Lithium was found to be at least as efficacious as chlorpromazine for treatment of acute mania in almost all controlled trials (Platman 1970; Spring et al. 1970; Johnson et al. 1971; Shopsin et al. 1975; Takahashi et al. 1975; Goodwin and Zis 1979). Two studies, however, found chlorpromazine (Prien et al. 1972a) and haloperidol (Garfinkel et al. 1980) to be better than lithium treatment. In this literature, there is an overall suggestion that lithium is more specific for the core manic symptoms (affective and ideational symptoms) as compared to neuroleptics; whereas, neuroleptics are apparently as good or better to control the psychomotor hyperactivity and agitation more rapidly (Johnson et al. 1971; Prien et al. 1972a; Goodwin and Zis 1979). Thus, most of the controlled trials corroborate the superiority of lithium over neuroleptics for bipolar mania, in terms of being more effective and more specific for the core manic symptoms. The effects of neuroleptics in this condition seem to involve nonspecific sedation.

The response rates in the treatment of mania have varied considerably on different samples of bipolar patients. In typical "pure" manic states, lithium is usually very effective, with response rates varying from 60 to 90\% (Himmelhoch et al. 1976; Secunda et al. 1985; Swann et al. 1986; Prien et al. 1988a; Dilsaver et al. 1993). However, about $40 \%$ of manic patients present with a mixed picture, with a combination of manic and depressive symptoms (Himmelhoch et al. 1976; McElroy et al. 1992a). These patients tend to have poorer response rates to lithium, varying from 29 to $42 \%$ (Himmelhoch et al. 1976; Secunda et al. 1985; Swann et al. 1986; Prien et al. 1988a; Dilsaver et al. 1993). Mania secondary to known medical conditions is also associated with poor response (Krauthammer and Klerman 1978). So, the more typical the bipolar manic states are, the higher the response rates with lithium.

Thus, acute treatment of mania is the primary indication for lithium, with findings of high effectiveness. Some recent trials have reported somewhat lower effectiveness, reflecting the presence of mixed state and atypical patients in the samples.

\section{Prophylaxis of Bipolar Disorder}

Initial open trials (Baastrup 1964; Hartigan 1963; Baastrup and Schou 1967) suggested that lithium was effective for prophylaxis of affective disorders. Early placebo-controlled studies (Baastrup et al. 1970; Coppen et al. 1971; Cundall et al. 1972; Dunner et al. 1976; Fieve et al. 1976; Hullin et al. 1972; Prien et al. 1973a,b, 1974; Stallone et al. 1973) corroborated that. The effectiveness for bipolar disorder prophylaxis is well documented in double-blind controlled trials, both for the manic and depressive phases of the disorder (Prien and Potter 1990; Price and Henninger 1994; Calabrese et al. 1995). 
In addition to this well-documented effectiveness, there are reports of high recurrence rates over the first few months after lithium discontinuation, which seem to be higher than the course of the untreated disorder (Mander 1986; Mander and Loudon 1988; Suppes et al. 1991; Goodwin 1994).

The reported effectiveness rates with lithium prophylaxis have changed over the years. The early controlled studies in bipolar patients found failure rates around 20 to $30 \%$, over varied periods of time (Baastrup et al. 1970; Coppen et al. 1971; Cundall et al. 1972; Hullin et al. 1972; Prien et al. 1973a; Stallone et al. 1973). A review of several controlled studies from the 1960s and 1970 s reported lithium to fail on average in $33 \%$ of cases (Prien 1988b). Most recent controlled studies have shown higher failure rates, with $55 \%$ reported in a large multicenter double-blind controlled study (Prien et al. 1984), and other naturalistic studies showing failure rates of 42 to over 70\% (Dickson and Kendell 1986; Shapiro et al. 1989; Harrow et al. 1990; Tohen et al. 1990a,b; Maj et al. 1991; O'Connell et al. 1991; Keller et al. 1993; Peselow et al. 1994; Coryell et al. 1995). In a recent study of lithium prophylaxis in bipolar and schizoaffective patients (Coryell et al.), high relapse rates were reported; the likelihood of at least one recurrence after 5 years exceeded $70 \%$. The differential outcome in the group of bipolar versus schizoaffective disorder patients was not reported. The report of the National Institute of Mental Health (NIMH) workshop on the treatment of bipolar disorder (Prien and Potter 1990) suggested that lithium is overall ineffective in $20-40 \%$ of bipolar patients, particularly those with rapid cycling or dysphoric mania.

The characteristics of the lithium responders has been extensively studied. Classic manic states and mania followed sequentially by euthymia and depression predict good prognosis on lithium prophylaxis (Maj et al. 1989; Faedda et al. 1991; Bowden et al. 1994). Mania with mixed or dysphoric features, rapid-cycling patients, and mania secondary to medical conditions respond poorly to lithium (Prien 1988b; McElroy et al. 1992a; Dilsaver et al. 1993; Keller et al. 1993; Sharma and Persad 1994). Patients with high frequency of previous episodes (Sarantidis and Waters 1981; AbouSaleh and Coppen 1986) and comorbid substance abuse or personality disorders (Abou-Saleh and Coppen 1986; Kutcher et al. 1990; Gaviria et al. 1982; Abou-Saleh 1983; Maj 1984) are also less responsive. Family history of mood disorders is related to better response to lithium prophylaxis (Maj 1984; Abou-Saleh and Coppen 1986). In another study (Mendlewicz and Stallone 1975), family history of bipolar disorder, but not unipolar, was shown to be related to positive lithium response. This family data, if confirmed, also point to a specificity of lithium for bipolar disorder. Grof et al. (1993) recently readdressed this question and found that a primary di- agnosis of affective disorder, episodic course, and family history of bipolar illness were the best predictors of lithium's response in the maintenance treatment. They suggested that typical bipolar patients tend to respond well, and the more atypical features they have, the worse the response. In the bipolar II population, lithium is also an effective prophylactic treatment (Dunner et al. 1976; Kane et al. 1982). It is effective in the prophylaxis of hypomanic episodes, but may not reduce the frequency of depressive episodes; however, the depressive episodes may be less severe (Dunner et al. 1976). Thus, lithium has high effectiveness in the prophylaxis of bipolar disorder, types I and II. It is not as effective in atypical bipolars, rapid cyclers, organic mania, dysphoric mania, and patients with comorbid psychiatric disorders. These studies of predictors of lithium response also give strong support for the idea of lithium's specificity, with typical features predicting a favorable response.

The decreasing effectiveness rates in bipolar disorder reported with lithium have been extensively debated in the recent literature (Guscott and Taylor 1994; Goodwin 1995; Moncrieff 1995; Gershon and Soares, 1997). The explanation for this may be multifactorial. First, patients referred to academic medical centers nowadays, as a result of widespread lithium use, may be more severe, refractory cases, with more atypical features and comorbid psychopathology. Second, bipolar disorder has become a more inclusive category over the years, with some patients previously classified as schizoaffective or schizophrenic now being classified in this group. Third, in more recent trials, there has been a significant proportion of patients who had already failed lithium therapy at the time of enrollment in the study. Fourth, it may be caused by changes in the presentation of the disorder over the years, mostly as a result of more available treatment options, some with the potential to actually complicate the course of the disease, e.g., tricyclic antidepressants (Wehr and Goodwin 1987).

Some authors feel that many years of lithium treatment have not had a significant impact on the epidemiology of bipolar disorder (Moncrieff 1995). Guscott and Taylor (1994) proposed that poor compliance to the medication and underprescribing could account for this. Alternatively, Moncrieff pointed to methodological flaws in the early lithium trials as a potential explanation, which may have overestimated the effects of lithium. Some were retrospective comparisons of the course of the disorder before and after lithium, and some were discontinuation trials, with a number of the patients who entered the placebo group having been on lithium before the trial. Therefore, according to these authors, the outcome of lithium treatment was not clearly superior to the course of the untreated disorder. Nonetheless, these strong criticisms are not endorsed by most authors (Goodwin 1995; Gershon and Soares 
1997) and do not invalidate data of the many controlled trials with a positive lithium effect.

\section{Bipolar Depression}

Depressed patients with a previous history of mania or hypomania are more likely to respond to lithium than patients without such previous episodes (Goodwin et al. 1972; Noyes et al. 1974; Mendels 1979). Antidepressant effects of lithium have been more clearly demonstrated in depressed bipolars than in unipolars (Baron et al. 1975). Depression associated with bipolar disorder has been regarded as a more severe depression, which may be more difficult to treat, and lithium treatment is beneficial (Goodwin et al. 1972; Noyes et al. 1974; Baron et al. 1975; Fieve et al. 1976; Mendels et al. 1972; Mendels 1979). However, for acute treatment of depression, antidepressants are the most effective agents. In bipolar depression, monoamine oxidases (MAOIs) have been suggested to be particularly effective (Quitkin et al. 1981a; Himmelhoch et al. 1991).

Thus, lithium is effective for treatment of depression in bipolar disorder, seemingly more so than in unipolar depression (Baron et al. 1975). However, it is not as effective as antidepressants. The findings of more specific effects of lithium in depression associated with bipolar disorder are also in agreement with the suggestion of lithium's specificity for this disorder.

\section{Unipolar Depression}

Initial open trials (Johnson 1974; Watanabe et al. 1974; Worrall et al. 1979) and double-blind controlled studies found lithium effective for unipolar depression (Mendels et al. 1972; Fieve et al. 1975; Khan et al. 1987). In some studies, it was found to be as effective as antidepressants (Mendels et al. 1972; Watanabe et al. 1975; Worrall et al. 1979; Quitkin et al. 1981b; Linder et al. 1989). Mendels (1979) reviewed 10 controlled studies of lithium as treatment of depression, and seven of these reported significant antidepressant effects. Overall, the response rates reported for lithium in the acute treatment of unipolar depression have been about 30 to $40 \%$, which is lower than the rates for bipolar depression or the rates with antidepressants (Goodwin and Jamison 1990).

In the prophylaxis of unipolar depression, lithium was better than placebo in most studies (Prien et al. 1973b; Fieve et al. 1975,1976; Kane et al. 1982; Glen et al. 1984). The only large double-blind controlled study that included a control group on antidepressants found that lithium was better than placebo, but not as effective as antidepressants, and that combination treatment did not result in additional benefits after a 2-year period (Prien et al. 1984). A recent double-blind placebo-con- trolled trial (Wilson et al. 1995) of lithium versus placebo (all patients also receiving cognitive behavior therapy) for the maintenance treatment of unipolar elderly depressed patients failed to find evidence of significant benefits.

Lithium is also a useful augmentation strategy in the treatment of depression, and this is supported by several controlled studies (Lingjaerde et al. 1974; Heninger et al. 1983; Schopf et al. 1989; Joffe et al. 1993; Stein and Bernadt 1993; Fava et al. 1994; de Montigny 1994; Ebert et al. 1995).

Thus, lithium has therapeutic effects in acute unipolar depression, but it is less effective than antidepressants. It seems to be less effective than in bipolar depression, which points to a more specific action in bipolar disorder. For prophylaxis of unipolar depression, antidepressants have been shown to be more effective.

\section{Schizoaffective Disorder}

The early literature on lithium as a treatment for schizoaffective disorder suggested that there were no significant benefits and that some patients could have worsening of thought disorder (Johnson et al. 1968). Johnson (1970) treated 19 manics and 11 schizoaffective patients, excited phase, with lithium or chlorpromazine under controlled conditions. In the manic group, 15 patients had remission, three improved, and one had no change. In the schizoaffective group, only one had remission, four improved, and six worsened. They concluded that lithium had a specific therapeutic action in bipolar disorder. In another report (Johnson et al. 1971) on a group of 21 bipolar manic patients and 13 schizoaffectives, excited phase, treated with lithium or chlorpromazine under double-blind conditions, lithium was highly effective for the bipolar patients, but did not have significant effects in the schizoaffective patients. Chlorpromazine, on the other hand, produced significant improvement in both groups. Subsequently, open trials suggested that schizoaffective patients had some response to lithium (Dinsmore and Ryback 1972; Smulevitch et al. 1974). Prien et al. (1972b) conducted a 3-week controlled trial of 83 schizoaffective patients, excited state, with lithium or chlorpromazine and found that for the highly active patients, chlorpromazine was superior, but in mildly active patients, both treatment groups had comparable improvement. Brockington et al. (1978) treated 19 schizoaffective patients, manic, with chlorpromazine or lithium under double-blind condition and failed to find significant differences between treatments. In a subsequent report (Brockington et al. 1980) found significant improvement on lithium in 24 or 32 schizoaffective patients, manic, in a retrospective analysis of patient's records. Miller and Libman (1979) reviewed the literature on lithium treatment of schizoaf- 
fective disorder and concluded that there was sparse evidence that some cases could benefit from lithium, particularly those with "psychomotor acceleration and periodicity." Because of these apparent effects, they proposed that those two "dimensions;" namely, psychomotor acceleration and periodicity, were the aspects that would confer "therapeutic predictability." Braden et al. (1982) compared lithium and chlorpromazine in a double-blind design in a sample that included a mixed group of schizophrenics, schizoaffectives, and moodincongruent psychotic affective disorder patients. The authors did not find a significant relationship between diagnostic group and treatment response. In overactive patients, chlorpromazine was more effective, and for the other patients, lithium and chlorpromazine were equally effective. However, when diagnostic groups were defined according to classification systems that took into consideration the course of the disorder (e.g., DSM-III or modified RDC), the schizophrenic patients responded significantly worse to lithium.

In the prophylactic treatment, Prien et al. (1974) found lithium to be substantially more effective in bipolars than schizoaffectives; three of five schizoaffectives had recurrence, as compared to only three of 86 in the bipolar group. Lithium was reported to be beneficial in "cycloid psychosis," which is an "endogenous" psychotic condition with symptoms of both schizophrenia and mood disorders that would roughly correspond to the diagnosis of schizoaffective disorder today (Perris 1978). In this study, 30 patients followed for periods of 1 to 8.5 years showed significant benefits on lithium, with "a favorable morbidity suppressive effect." Patients with schizoaffective disorder were found to benefit from lithium prophylaxis in a 2-year open trial (Maj 1984). The treatment response was better in "schizomanic" than in "schizodepressed" patients. In a subsequent study, Maj (1988) reported that lithium at blood levels between 0.6 to $1.0 \mathrm{mEq} / 1$ was helpful for prophylaxis of schizoaffective patients in a 2-year open trial, but those with a prominent schizophrenic-like component and those cross-sectionally diagnosed as "schizodepressed" had relatively poor response. Past bipolar course of the illness was associated with positive response.

Thus, the studies with lithium in schizoaffective disorder provide support for the hypothesis of lithium's specificity for bipolar disorder. Overall, the more bipolar features these patients have, the better is their response to lithium treatment.

There has been significant debate about the diagnostic category of schizoaffective disorder and whether it is really a separate entity as compared to bipolar disorder or schizophrenia. Some studies failed to distinguish manic bipolar patients from manic schizoaffective patients on the basis of clinical variables (Abrams and Taylor 1976; Pope et al. 1980; Kendell 1985). For these authors, the concept of schizoaffective-manic would be a redundancy and, actually, would be the same disorder as bipolar mania. Other authors (Crow 1990) have proposed that there would be a "genetic continuum" of psychotic disorders, extending from unipolar and bipolar disorder to schizophrenia, with several intermediate forms, corresponding to schizoaffective disorder. How to trace the dividing line, or what these forms mean in terms of pathophysiological mechanisms have yet to be answered. Evidence from the literature that the treatment response of the typical bipolar group is better than the schizoaffective-manic group suggests that they are two different entities.

\section{Schizophrenia}

Initial uncontrolled reports found no benefits of lithium treatment in schizophrenics (Cade 1949; Gershon and Yuwiler 1960). Shopsin et al. (1971) conducted a controlled study with 21 acute schizophrenic patients, treated with either lithium or chlorpromazine. They found that lithium had no effect in schizophrenic symptoms, and some of the schizophrenic patients got worse, developing symptoms of a "toxic-confusional state." Subsequently, a few small controlled trials suggested that some schizophrenic patients who were unresponsive to neuroleptics benefited from the addition of lithium (Growe et al. 1979; Alexander et al. 1979). In a sample of 31 schizophrenic and schizoaffective patients, Hirschowitz et al. (1980) found evidence of improvement in schizophrenic symptoms in nine patients after a 2-week lithium trial. However, seven of these nine lithium responders were actually classified as schizophreniform disorder according to DSM III. In a review of this literature, Delve and Letemendia (1982) suggested that there is evidence for some acute and prophylactic effects of lithium in schizophrenia and schizoaffective disorder. They acknowledged that, "At present, all that can be stated is that the use of lithium in the treatment of patients with schizophrenia or schizoaffective disorder remains empirical." In schizophrenia, they estimated that overall between one-third and one-half of patients could have some benefits from lithium treatment.

Garver et al. (1984) described a group of psychotic disorder patients who had some response to lithium. These patients were mostly classified as schizopheniform disorder, and may turn out in their course not to be schizophrenics. Zemlan et al. (1984a) reported a subgroup of schizophrenic patients that responded to lithium to some degree; in an open trial, these authors described improvement of at least $40 \%$ in such schizophrenic symptoms as hallucinations, delusions, and formal thought disorder. In another open trial report (Zemlan et al. 1984b), involving a group of 24 schizophrenic and schizoaffective disorder patients and six manics, eight were considered responders. They suggested that an- 
tipsychotic effects of lithium in the responders appeared selectively in mood-incongruent psychotic patients and were not present in mood-congruent psychotic patients (manics), contrary to the mood effects; however, these suggestions have not been confirmed further. Hirschowitz et al. (1982) treated a group of 31 schizophrenic and schizophreniform disorder patients in acute decompensation with 2 weeks of lithium. Only six patients improved; one met DSM III criteria for schizophrenia, and the others were schizophreniform disorder $(n=4)$ and mood incongruent psychosis, with manic features $(n=1)$. Of 25 patients with DSM III diagnosis of schizophrenia, $24(96 \%)$ did not respond to lithium.

The literature on the use of lithium in schizophrenia was reviewed by Atre-Vaidya and Taylor (1989), who concluded that three of seven double-blind studies available at that time did not support this practice. In the positive trials, the number of responders seemed too small to allow any definite conclusions. They suggested that a family history of affective disorder, active affective symptoms, and previous affective episodes predicted a favorable response.

A recent study (Schexnayder et al. 1995) shone further light on this question. A sample of 66 psychotic inpatients received a 2-week trial on lithium alone. These patients were mostly RDC schizophrenics $(n=54)$, and the rest were schizoaffective, depressed type $(n=12)$. Ten of 66 patients were classified as lithium responders; in this group, six were RDC schizophrenics, and four were schizoaffective, depressed; in the nonresponders, 48 were schizophrenics, and eight were schizoaffective disorder, depressed. The responders had significantly fewer negative symptoms and absence of familial schizophrenic spectrum disorders. This study supports the idea of lithium's specificity for bipolar disorder; however, it defines a small group $(6 / 54)$ of schizophrenic patients who could potentially benefit from lithium alone.

For some authors (Miller and Libman 1979), the cases of schizophrenia and schizoaffective disorder that respond to lithium are characterized by psychomotor acceleration and periodicity. These might be patients more accurately classified as schizoaffective disorder, if more stringent diagnostic definitions were used. Lithium responsiveness in psychotic patients has also been associated with smaller rates or absence of schizophrenia-spectrum disorders in family studies (Sautter and Garver 1985; Sautter et al. 1990).

Thus, most of the studies did not find substantial effects of lithium in schizophrenia. There may be a subgroup of schizophrenic patients who exhibit modest response to lithium, and this may be related to improvement of affective symptoms. Overall, in psychotic patients, the more affective symptoms, the higher the chances that they will respond to lithium.

\section{Aggressiveness}

Uncontrolled evidence suggested that lithium has therapeutic effects in aggressive behavior in early total deafness patients (Altshuler et al. 1977). DeLong (1978) reported benefits of lithium in 12 children with chronic behavioral disorders, all with hostility, aggressiveness, distractibility, and family history for depression, alcoholism and bipolar disorder. An open trial (Siassi 1982) found lithium effective in the treatment of aggressiveness in 14 children with significant reduction in unprovoked aggressive outbursts. In mentally retarded patients with episodes of aggressiveness and self-mutilatory behavior, lithium was suggested to produce significant therapeutic effects (Dostal and Zvolsky 1970; Naylor et al. 1974; Goetzl et al. 1977). Controlled trials in prison inmates with "chronic assaultive behavior or chronic impulsive antisocial behavior" have shown therapeutic effects for aggressiveness (Sheard et al. 1976; Marini and Sheard 1977). In double-blind, placebo-controlled studies, lithium was significantly better than placebo in decreasing aggressive scores and frequency of aggression episodes in mentally handicapped children (Craft et al. 1987) and adults (Tyrer et al. 1984). One double-blind, placebo-controlled, cross-over discontinuation study (DeLong and Nieman 1983) showed that lithium had significant effects in decreasing cyclic aggressiveness, violent explosive behavior, restlessness, and mood swings in children. In children with conduct disorder and adolescents, there is some evidence that lithium can reduce aggressiveness. A recent double-blind placebo-controlled study involving 50 children with conduct disorder showed lithium effective in reducing symptoms of fighting, temper outbursts, and bullying (Campbell et al. 1995a).

Thus, lithium may have significant effects on episodic aggressive behavior. These conditions have the cyclicity present in bipolar disorders, and the nature of this relationship is still not understood. Thus, lithium could have specific action in conditions where cyclicity and episodes of aggression/hyperactivity are important features.

\section{Alcoholism and Other Substance Abuse}

The initial controlled trial suggested that lithium had therapeutic effects on alcoholism (Wren et al. 1974). In a double-blind placebo-controlled prospective study (Merry et al. 1976), it had significant effects in depressed alcoholics, with reduced drinking and incapacity, but not in the nondepressed group. It was suggested to antagonize the effects of ethanol intoxication in alcoholics (Judd and Huey 1984). In another double-blind trial, lithium had positive effects on drinking behavior in alcoholics, which seemed to be independent of effects on affective symptoms (Fawcett et al. 1987). Other con- 
trolled double-blind trials, however, failed to show significant effects of lithium (Pond et al. 1981; Dorus et al. 1989). Dorus et al. reported the results of a large Department of Veteran Affairs (VA) collaborative study involving 457 depressed and nondepressed alcoholics. No significant effects of lithium were found in either patient group. As discussed in a recent review of this literature, large double-blind trials failed to demonstrate significant effects of lithium in either depressed or nondepressed alcoholics (Lejoyeux and Ades 1993).

Lithium was also examined for the treatment of other substance abuse/dependencies, without evidence of significant effects. In a small series, it was suggested to be beneficial for the treatment of cocaine-induced psychosis (Scott and Mullaly 1981). Others suggested its usefulness in antagonizing cocaine-induced "highs" (Cronson and Flemenbaum 1978). However, there is no controlled evidence supporting its effectiveness in any of these conditions.

\section{Other Neuropsychiatric and Medical Conditions}

In premenstrual tension, placebo-controlled studies did not find evidence of effectiveness (Sletten and Gershon 1966; Mattsson and von Schoultz 1974; Singer et al. 1974). In obsessive-compulsive disorder, controlled studies have produced negative results (Geisler and Schou 1973; McDougle et al. 1991). Anecdotal reports accounted for some effectiveness in affective disorders caused by organic brain syndromes (Young et al. 1977; Rosenbaum and Barry 1975; Mehta 1976), or drug-induced affective disorder (van Woert et al. 1971; Horowitz, 1975; Ryback and Schwab 1971; Braden 1977), but no controlled studies have examined this question. Anecdotal reports also suggested that it might be effective in the treatment of compulsive gambling (Moskowitz 1980). There have also been reports of lithium being beneficial for periodic hypersomnia states, such as Kleine-Levin syndrome (Jeffries and Lefebvre 1973; Ogura et al. 1976; Abe 1977; Will et al. 1988); however, these are not double-blind, controlled studies. No conclusive evidence of significant effects of lithium in nondepressed eating disorder patients has been found in controlled studies. Overall, lithium's effectiveness has been examined in a wide variety of neuropsychiatric and medical conditions, in some cases in controlled studies, without conclusive findings of beneficial effects.

\section{OTHER AGENTS FOR TREATMENT OF BIPOLAR DISORDER}

Valproate and carbamazepine have been proposed as alternatives to lithium treatment in manic-depressive patients (Okuma 1973, 1983; Ballenger and Post 1980; Post, 1982; Post et al. 1983, 1991; Ballenger 1988; Prien and Gelenberg 1989; Keck et al. 1992; Potter and Bowden 1992). In recent years, there have been claims that they are as effective as lithium, and they could be even more effective than lithium in some atypical patients (Bowden 1995). An analysis of the comparative effectiveness of these agents in bipolar disorder may help us address the question of lithium's specificity for the treatment of this disorder.

\section{Carbamazepine}

Several controlled studies corroborated carbamazepine's effectiveness in the acute treatment of mania and perhaps prophylaxis of the disorder (Okuma et al. 1979, 1990; Coxhead et al. 1992; Lusznat et al. 1988; Small et al. 1991; Watkins et al. 1987). Most studies found it to be comparable to lithium in effectiveness, except for three studies (Okuma et al. 1981; Lerer et al. 1987; Watkins et al. 1987). However, for prophylactic treatment, according to a recent meta-analysis of this literature (Dardennes et al. 1995), the effectiveness of carbamazepine remains to be established. It has been suggested to be effective in lithium-resistant patients (Post et al. 1983; Di Constanzo and Schifano 1991), rapid-cycling patients (Post et al. 1983, 1987), dysphoric/mixed states (Post et al. 1987; Ballenger, 1988), and patients with neurological abnormalities (Folks et al. 1982).

Does carbamazepine have specificity in the treatment of bipolar disorder? One open trial (Elphick 1985) involving 11 bipolar disorder and schizoaffective patients suggested carbamazepine to be useful for the acute and prophylactic treatment of bipolar patients. In the schizoaffective patients, the response was much less marked, suggesting some specificity for bipolar disorder. Placidi et al. (1986) followed 83 psychotic patients (major affective, schizoaffective, schizophreniform disorders) for 3 years in a double-blind trial of lithium versus carbamazepine and found comparable effectiveness; however, significantly increased dropout rates were found among patients with mood-incongruent psychotic features who were assigned to lithium. In schizophrenic patients, carbamazepine has been tried under double-blind conditions as the exclusive maintenance treatment, with negative findings (Carpenter et al. 1991). It has been suggested to be effective in the treatment of psychosis nonresponsive to neuroleptics (Neppe 1988), mainly in patients with aggression, instability and agitation. There are suggestions that increased manic severity, anxiety, dysphoria, rapid cycling, negative family history, known to be predictors of poor lithium response, may be associated with positive response to carbamazepine (Post et al. 1987).

Thus, carbamazepine seems effective in the treatment of acute mania. However, its effectiveness may not be as high as lithium's, and its scope of action seems 
broader, being also effective in other psychotic conditions.

\section{Valproate}

Valproate was first proposed in the mid-60s for the treatment of mania (Lambert et al. 1966). Freeman et al. (1992) reported a 3-week double-blind trial of valproate and lithium in mania. Both drugs produced significant improvement, but lithium was slightly better. Valproate seemed more effective in patients with high pretreatment depression scores, suggesting that it may be more effective in mixed affective states. Clothier et al. (1992) in a double-blind study, compared lithium and valproate in 27 manic bipolars; the valproate responders had higher pretreatment depressive scores. A recent large 3-week double-blind, placebo-controlled trial (Bowden et al. 1994) compared valproate and lithium in 179 inpatients with a diagnosis of mania. In this trial, both treatments were comparable, and significantly better than placebo, with rates of improvement with lithium of $49 \%$, valproate of $48 \%$, and placebo of $25 \%$. However, $86 \%$ of the patients in the lithium group had been on lithium, and $48 \%$ did not respond or did not tolerate it previously. Thus, about half of these patients were already known to be lithium nonresponders. This weakens the conclusions to be drawn from this study concerning the comparative effectiveness of these two drugs in the treatment of mania. In this study, valproate was reported to be as effective for rapid cyclers as nonrapid cycling manics. Valproate seems less effective in schizoaffective disorder than bipolar disorder (Emrich et al. 1985; McElroy et al. 1987, 1992b).

There is evidence suggesting that valproate may be particularly effective in patients with rapid cycling, dysphoric or mixed mania, and neurologic abnormalities (McElroy et al. 1992b). In one report (Stoll et al. 1994), bipolar disorder and schizoaffective patients with neurological abnormalities had a "higher rate of good response" than neurologically normal patients (43.6 and $24.3 \%$, respectively). It has also been proposed as an augmentation strategy in patients refractory to lithium. A retrospective chart review of refractory bipolar patients treated with valproate augmentation found response rates of $71 \%$. This study included patients with abnormal EEG, CT, or neurological findings (McCoy et al. 1993).

No controlled trials with valproate for the maintenance treatment of bipolar disorder have been reported. Retrospective studies suggested that it may be useful (Fogelson et al. 1991; McElroy et al. 1988; Hayes 1992). Uncontrolled trials support this view (Emrich et al. 1985; Puzynski and Klosiewicz 1984; Lambert 1984; Calabrese and Delucchi 1990; Calabrese et al. 1992). They suggest that it reduces the frequency and intensity of manic and depressive episodes over long periods of time; acute and prophylactic antidepressant effects seem to be less robust than antimanic effects. Additionally, the great majority of these uncontrolled studies have used valproate in combination with other medications, such as antidepressants, lithium, neuroleptics, and benzodiazepines, making definitive conclusions on prophylaxis difficult.

Thus, valproate is an effective treatment for acute mania and, perhaps, prophylaxis of bipolar disorder. Valproate, as does carbamazepine, seems to have some degree of specificity for bipolar disorder as compared to other psychiatric disorders; however, both drugs have a broader scope of action than lithium.

\section{Electroconvulsive Therapy}

ECT has been shown to be very effective for acute and perhaps prophylactic treatment of bipolar disorder (Schou 1991). Three studies compared lithium and ECT for the treatment of mania. Two were retrospective studies; one found no significant differences between ECT and lithium (Thomas and Reddy 1982), and the other found a significantly greater percentage of patients with marked improvement in the ECT group (Black et al. 1987). The prospective study (Small et al. 1988) investigated a group of 34 manic bipolar patients, randomly allocated to lithium or bilateral ECT, followed by lithium maintenance. Patients in the ECT group did better on the first 8 weeks, but after that there were no significant differences between groups.

There is also evidence that ECT is effective in manic patients refractory to medications. One open study (Schnur et al. 1992) in 18 manics nonresponsive to medication found a $66 \%$ response rate; dysphoric and psychotic symptoms predicted worse response. In a retrospective study, Small et al. (1985) suggested that for mania bilateral ECT was more effective than unilateral. The use of ECT in the prophylaxis of bipolar disorder is more controversial and remains to be a systematically investigated. As pointed out in a recent review (Schou 1991), "the prophylactic value of maintenance ECT remains under dispute." The therapeutic effects of ECT for acute treatment of depression in unipolars and bipolars are well-recognized. Thus, ECT seems to be beneficial for the acute treatment and perhaps prophylaxis of bipolar disorder. No evidence of specificity for this condition exists, because ECT has well-known benefits in a variety of other conditions.

\section{NEUROCHEMICAL FINDINGS}

Lithum acts on different neurotransmitter and signal transduction systems. It blocks the development of dopamine-receptor supersensitivity, enhances GABA, serotonin and acetylcholine function, decreases alpha ${ }_{2}-$ 
adrenoceptor function, decreases neurotransmitter-stimulated adenylate cyclase activity and cyclic AMP formation, decreases $G$ protein coupling to receptors, inhibits the phosphoinositide (PI) pathway, and interferes with membrane exchange of cations such as $\mathrm{Na}^{+}, \mathrm{K}^{+}, \mathrm{Ca}^{2+}$, and $\mathrm{Mg}^{2+}$ (Price and Heninger 1994). The clinical relevance of these different neuropharmacological mechanisms is not understood.

Decreased GABA function may be present in patients with mood disorders. Findings of decreased CSF and plasma GABA levels in patients with depression, and decreased plasma levels in patients with mania have been reported (Petty 1995). Valproic acid, ECT, and antidepressants interfere with gabaergic transmission, reducing plasma GABA, and treatment response may correlate with higher baseline plasma GABA levels (Petty). Lithium, on the other hand, seems to enhance gabaergic activity (Price and Heninger 1994). The anticonvulsants may benefit bipolar disorder patients by interfering with gabaergic neurotransmission. It has been proposed that they alter the "kindling" process in temporal and limbic structures, which may be relevant in the pathophysiology of bipolar disorder (Post 1982, 1986, 1992). Valproate and carbamazepine are more specific to seizure activity in the limbic system as compared to other anticonvulsants (Albright and Burnham 1980), and this may be why they are beneficial for the treatment of bipolar disorder.

Lithium is known to enhance brain cholinergic function, by its presynaptic effects on acetylcholine turnover and release (Lerer 1985). These effects are actually opposite to ECT effects on brain cholinergic systems. ECT acutely promotes release of ACh during the seizure, but with chronic treatment, it seems to decrease cholinergic transmission, by down-regulating postsynaptic muscarinic cholinergic receptors (Lerer 1985). Because both treatments have been found effective in mania, it is not known how these actions relate to the beneficial effects of these treatments.

A focus of this research over the past few years has turned to the action of lithium and other drugs effective in this condition on signal transduction mechanisms (Baraban et al. 1989; Manji and Lenox 1994; Manji et al. 1995). Lithium inhibits the enzyme inositol monophosphatase (IMPase), resulting in attenuation of the phosphatidylinositol (PI) signal transduction pathway, which is believed to be a main step in its mechanism of action (Atack et al. 1995). This inhibition results in increased levels of myo-inositol monophosphates, and decreased myo-inositol for the resynthesis of inositol phospholipids, with an exhaustion of inositol stores. However, in preparations derived from bovine brains, this has not been found to be a mechanism shared by other drugs effective in this disorder; e.g., valproate and carbamazepine (Vadnal and Parthasarathy 1995). In this study, lithium was found to inhibit the IMPase activity in the millimolar range, carbamazephine was found to stimulate IMPase, and valproate did not have either stimulatory or inhibitory actions. This suggests that inhibition of IMPase is not a common neurochemical mechanism for the different mood-stablilizing medications. Other mechanisms, such as interference with protein kinase $\mathrm{C}$ (PKC) regulation, and other steps of the signal transduction pathways may be important in their therapeutic action. There is recent evidence from human studies suggesting that lithium and verapamil in therapeutic doses decrease PKC activity in platelets and lymphocytes (Friedman et al. 1993; DePetrillo et al. 1994).

Increased baseline intracellular $\mathrm{Ca}^{2+}$ levels and agonist-stimulated response have been reported in unmedicated bipolar patients, in the manic state (Dubovsky et al. 1989, 1991, 1992, 1994). Lithium seems to decrease intracellular $\mathrm{Ca}^{2+}$ levels and agonist-stimulated $\mathrm{Ca}^{2+}$ response (van Calker et al. 1993; Forstner et al. 1994). The increased $\mathrm{Ca}^{2+}$ levels reported in manics is consistent with a hyperfunctional PI cycle, which may be an important pathophysiological mechanism in bipolar disorder. $\mathrm{Ca}^{2+}$ channel blockers, which appear to be effective in the treatment of mania, act by attenuating this increased $\mathrm{Ca}^{2+}$ function. The characterization of how anticonvulsants and other drugs effective in this condition interact with intracellular $\mathrm{Ca}^{2+}$ function may lead to better understanding of their mechanisms of action.

Most of the difficulty in research attempting to elucidate the biological and biochemical underpinnings of bipolar disorder comes from the fact that a satisfactory animal model to study the disorder has not yet been developed. The main elements of the bipolar pathophysiology are very difficult to simulate. Laboratory research in this area has mostly been restricted to the study of particular neurotransmitter systems believed to be important in this disorder. Recent developments in this field bring more promise. Antelman et al. (1995) have recently described a model of oscillation in different cellular systems after overstimulation by stressors or drugs, that could reflect what happens in the brain neurons in bipolar and mood disorders. Interestingly, lithium administration in concentrations similar to the therapeutic concentrations used in humans seems to lead to cessation of this oscillation (personal communication). This is a very exciting new area of research that may result in substantial development in the understanding of the pathophysiology of bipolar disorder, and therefore, of lithium specificity in this condition.

Thus, anticonvulsants may share some common mechanisms of action, which probably underlie their effectiveness in bipolar disorder. Some possible mechanisms would be their effects of GABA receptor channels, calcium or sodium channels, and signal transduction pathways. The neurochemical underpinnings of lithium's specificity in bipolar disorder are not understood. 


\section{CONCLUSIONS}

The research findings accumulated over the past several years support Cade's original proposition (Cade 1949) that lithium is most effective in bipolar disorder, as compared to other neuropsychiatric conditions. It is particularly beneficial for the acute treatment of mania and for prophylaxis, and also has positive effects in the treatment of depression in these patients. Despite evaluation in a broad range of different psychiatric conditions since its introduction into clinical use, its actions in no other psychiatric condition parallels the effects seen for typical bipolar patients, when examined in controlled clinical trials. Thus, lithium seems to constitute a specific treatment for bipolar disorder.

Consistent therapeutic benefits of lithium treatment were also found in episodic aggressiveness. Lithium seems to be beneficial in conditions with episodic, paroxysmal aggression and hyperactivity. These conditions have similarities with bipolar disorder because of their episodic course and agitation/hyperactivity. In schizoaffective disorder, the more the patients resemble bipolar disorder (with more affective symptoms and cyclicity), the higher the chances of response. In schizophrenia and other neuropsychiatric conditions, it may have some nonspecific sedating effects but usually few consistent therapeutic effects. The schizophrenia studies overall show that in rigorously diagnosed schizophrenics who do not have associated affective symptoms, there is no evidence that lithium is of therapeutic value (Atre-Vaidya and Taylor 1989).

Some authors have proposed that lithium's effectiveness may not be restricted to a particular disorder, but rather to a specific cluster of different disorders that have as common characteristics recurrent episodic presentation alternating with intervals of remission (Tupin 1972; Miller and Libman 1979). However, the data suggest that lithium is most effective in typical bipolar disorder patients, rather than in a particular cluster of disorders or symptoms.

What are the implications of the data reviewed here for the understanding of the pathophysiology of bipolar disorder? Bipolar disorder seems to be a very particular psychotic disorder whose pathophysiological mechanisms are positively affected by lithium treatment, in a unique way. The neurochemical mechanisms that confer this specificity are not yet known. Lithium has variable effectiveness in schizoaffective patients, depending upon on how close their clinical picture is to bipolar disorder and the prominence of affective symptoms. No significant therapeutic effects are present in schizophrenia. A critical question about the etiology of the disorder, based on the observed specificity of the lithium ion, to be addressed in future studies is: What are the pathophysiological mechanisms present in bipolar disorder, and not present or corrected in schizophrenia or other neuropsychiatric disorders, that lithium affects?
Promising research has begun, looking at lithium's action on different steps of the cellular signal transduction pathways (Baraban et al. 1989; Manji and Lenox 1994; Manji et al. 1995). The development of new drugs with the ability to inhibit the inositol monophosphatase is a current area of research (Kofman and Belmaker 1993; Atack et al. 1995) and may prove to be a useful approach to drug development in this field, although this does not seem to be a common mechanism of action for the treatments effective in this condition.

In conclusion, lithium is a specific treatment for bipolar disorder, and the study of this paradigm may result in better understanding of the pathophysiology of this condition. The study of pathophysiological mechanisms in lithium responders, across diagnostic categories, and the identification of common mechanisms of action for the treatment modalities that are beneficial for this condition, can shed further light into the basic mechanisms underlying lithium specificity. This model of specificity, unparalleled in psychiatry research, should be further explored, as a potential fruitful paradigm to understand the pathophysiology of this disorder.

\section{REFERENCES}

Abe K (1977): Lithium prophylaxis of periodic hypersomnia. Brit J Psychiat 130:312-316

Abou-Saleh MT (1983): Platelet MAO: Personality and response to lithium prophylaxis. J Aff Dis 5:55-65

Abou-Saleh MT, Coppen A (1986): Who responds to prophylactic lithium? J Aff Dis 10:115-125

Abrams T, Taylor MA (1976): Mania and schizo-affective disorder, manic type: A comparison. Am J Psychiat 133: 1445-1447

Albright PS, Burnham WM (1980): Development of a new pharmacological seizure model: Effects of anticonvulsants on cortical and amygdala-kindled seizures in the rat. Epilepsia 21:681-689

Alexander PE, van Kammen DP, Bunney WE Jr (1979): Antipsychotic effects of lithium in schizophrenia. Am J Psychiat 136:283-287

Altshuler KZ, Abdullah S, Rainer JD (1977): Lithium and aggressive behavior in patients with early total deafness. Dis Nerv Syst 38:521-524

Antelman SM, Caggiula AR, Kiss S, Edwards DJ, Kocan D, Stiller R (1995): Neurochemical and physiological effects of cocaine oscillate with sequential drug treatment: Possibly a major factor in drug variability. Neuropsychopharmacology 12:297-306

Atack JR, Broughton HB, Pollack SJ (1995): Inositol monophosphatase-A putative target for $\mathrm{Li}^{+}$in the treatment of bipolar disorder. Trend Neurosci 18:343-349

Atre-Vaidya N, Taylor MA (1989): Effectiveness of lithium in schizophrenia: Do we really have an answer? J Clin Psychiat 50:170-173 
Baastrup PC (1964): The use of lithium in manic depressive psychosis. Comp Psychiat 5:396-408

Baastrup PC, Schou M (1967): Lithium as a prophylactic agent. Arch Gen Psychiat 16:162-172

Baastrup PC, Poulsen JC, Schou M, Thomsen K, Amdisen A (1970): Prophylactic lithium: Double-blind discontinuation in manic-depressive and recurrent-depressive disorders. Lancet 2:326-330

Ballenger JC (1988): The use of anticonvulsants in manicdepressive illness. J Clin Psychiat 49:21-25

Ballenger JC, Post RM (1980): Carbamazepine in manicdepressive illness: A new treatment. Am J Psychiat 137(7):782-790

Baraban JM, Worley PF, Snyder SH (1989): Second messenger systems and psychoactive drug action: Focus on the phosphoinositide system and lithium. Am J Psychiat 146:1251-1260

Baron M, Gershon ES, Rudy V, Jonas WZ, Buchsbaum M (1975): Lithium carbonate response in depression. Prediction by unipolar-bipolar illness, average-evoked response, catechol-O-methyl transferase, and family history. Arch Gen Psychiat 32:1107-1111

Black DW, Winokur G, Nasrallah A (1987): Treatment of mania: A naturalistic study of electroconvulsive therapy versus lithium in 438 patients. J Clin Psychiat 48:132-139

Bowden CL, Brugger AM, Swann AC, Calabrese JR, Janicak PG, Petty F, Dilsaver SC, Davis JM, Rush AJ, Small JG, Garza-Trevino ES, Risch SC, Goodnick PJ, Morris DD (1994): Efficacy of divalproex vs. lithium and placebo in the treatment of mania. The Depakote Mania Study Group. JAMA 271:918-924.

Bowden CL (1995): Predictors of response to divalproex and lithium. J Clin Psychiat 56:25-30

Braden W (1977): Response to lithium in a case of L-dopainduced psychosis. Am J Psychiat 134:808-809

Braden W, Fink EB, Qualls CB, Ho CK, Samuels WO (1982): Lithium and chlorpromazine in psychotic inpatients. Psychiat Res 7:69-81

Brockington IF, Kendell RE, Kellett JM, Curry SH, Wainwright S (1978): Trials of lithium, chlorpromazine, and amitriptyline in schizoaffective patients. Brit J Psychiat 133:162-168

Brockington IF, Wainwright S, Kendell RE (1980): Manic patients with schizophrenic or paranoid symptoms. Psycholog Med 10:73-83

Cade JFJ (1949): Lithium salts in the treatment of psychotic excitement. Med J Australia 14:349-352

Calabrese JR, Delucchi GA (1990): Spectrum of efficacy of valproate in 55 patients with rapid-cycling bipolar disorder. Am J Psychiat 147:431-434

Calabrese JR, Markovitz PJ, Kimmel SE, Wagner SC (1992): Spectrum of efficacy of valproate in 78 rapid-cycling bipolar patients. J Clin Psychopharmacol 12:53-56

Campbell M, Adams PB, Small AM, Kafantaris V, Silva RR, Shell J, Perry R, Overall JE (1995a): Lithium in hospitalized aggressive children with conduct disorder. A double-blind and placebo-controlled study. J Am Acad Child Adolesc Psychiat 34:445-453

Carpenter WT, Kurz R, Kirkpatrick B, Hanlon TE, Summerfelt T, Buchanan RW, Waltrip RW, Breier A (1991): Car- bamazepine maintenance treatment in outpatient schizophrenics. Arch Gen Psychiat 48:69-72

Clothier J, Swann AC, Freeman T (1992): Dysphoric mania. J Clin Psychopharmacol 12:13S-16S

Coppen A, Noguera R, Bailey J, Burns BH, Swani MS, Hare EH, Gardner R, Maggs R (1971): Prophylactic lithium in affective disorders-Controlled trial. Lancet, August, 275-279

Coryell W, Endicott J, Maser JD, Mueller T, Lavori P, Keller M (1995): The likelihood of recurrence in bipolar affective disorder: The importance of episode recency. J Aff Dis 33:201-206

Coxhead N, Silverstone T, Cookson J (1992): Carbamazepine versus lithium in the prophylaxis of bipolar affective disorder. Acta Psychiat Scand 85:114-118

Craft M, Ismail IA, Krishnamurti D, Mathews J, Regan A, Seth RV, North PM (1987): Lithium in the treatment of aggression in mentally handicapped patients. A doubleblind trial. Brit J Psychiat 150:685-689

Cronson AJ, Flemenbaum A (1978): Antagonism of cocaine highs by lithium. Am J Psychiat 135:856-857

Crow TJ (1990): Continuum of psychoses and its genetic origins. The Sixty-Fifth Maudsley Lecture. Brit J Psychiat 150:788-797

Cundall RL, Brooks PW, Murray LG (1972): A controlled evaluation of lithium prophylaxis in affective disorders. Psycholog Med 2:308-311

Dardennes R, Even C, Bange F, Heim A (1995): Comparison of carbamazepine and lithium in the prophylaxis of bipolar disorders-A meta-analysis. Brit J Psychiat 166: 378-381

DeLong GR (1978): Lithium carbonate treatment of select behavior disorders in children suggesting manic-depressive illness. J Pediat 93:689-694

DeLong GR, Nieman GW (1983): Lithium-induced behavioral changes in children with symptoms suggesting manicdepressive illness. Psychopharmacol Bull 19:258-265

Delve NJ, Letemendia FJJ (1982): Lithium treatment in schizophrenia and schizo-affective disorders. Brit J Psychiat 141:387-400

de Montigny C (1994): Lithium addition in treatment-resistant depression. Int Clin Psychopharmacol 9:31-35

DePetrillo PB, Abernethy DR, Wainer IW, Andrawis NS (1994): Verapamil decreases lymphocyte protein kinase C activity in humans. Clin Pharmacol Therapeu 55:44-49

Dickson WE, Kendell RE (1986): Does maintenance lithium therapy prevent recurrences of mania under ordinary clinical conditions? Psycholog Med 16:521-530

Di Constanzo E, Schifano F (1991): Lithium alone or in combination with carbamazepine for the treatment of rapidcycling bipolar affective disorder. Acta Psychiat Scand 83:456-459

Dilsaver SC, Swann AC, Shoaib AM, Bowers TC, Halle MT (1993): Depressive mania associated with response to antimanic agent. Am J Psychiat 150:1548-1551

Dinsmore PR, Ryback R (1972): Lithium in schizo-affective disorders. Dis Nerv Syst December, 771-776

Dorus W, Ostrow DG, Anton R, Cushman P, Collins JF, Schaefer M, Charles HL, Desai P, Hayashida M, Malkerneker U, Willenbring M, Fiscella R, Sather MR (1989): 
Lithium treatment of depressed and nondepressed alcoholics. JAMA 262:1646-1652

Dostal T, Zvolsky P (1970): Antiaggressive effect of lithium salts in severe mentally retarded adolescents. Int Pharmacopsychiat 5:203-207

Dubovsky SL, Christiano J, Daniell LC, Franks RD, Murphy J, Adler L, Baker N, Harris A (1989): Increased platelet intracellular calcium concentration in patients with bipolar affective disorder. Arch Gen Psychiat 46:632-638

Dubovsky SL, Lee C, Christiano J, Murphy J (1991): Elevated platelet intracellular calcium concentration in bipolar depression. Biolog Psychiat 29:441-450

Dubovsky SL, Murphy J, Thomas M, Rademacher J (1992): Abnormal intracellular calcium ion concentration in platelets and lymphocytes of bipolar patients. Am J Psychiat 149:118-120

Dubovsky SL, Thomas M, Hijazi A, Murphy J (1994): Intracellular calcium signalling in peripheral cells of patients with bipolar affective disorder. Eur Arch Psychiat Clin Neurosci 243:229-234

Dunner DL, Stallone F, Fieve RR (1976): Lithium carbonate and affective disorders. V: A double-blind study of prophylaxis of depression in bipolar illness. Arch Gen Psychiat 33:117-120

Ebert D, Jaspert A, Murata H, Kaschka WP (1995): Initial lithium augmentation improves the antidepressant effects of standard TCA treatment in nonresistant depressed patients. Psychopharmacology 118:223-225

Elphick M (1985): An open trial of carbamazepine in treatment-resistant bipolar and schizo-affective psychotics. Brit J Psychiat 147:198-200

Emrich HM, Dose M, von Zerssen D (1985): The use of sodium valproate, carbamazepine, and oxcarbazepine in patients with affective disorders. J Aff Dis 8:243-250

Faedda GL, Baldessarini RJ, Tohen N, Strakowski SM, Waternaux C (1991): Episode sequence in bipolar disorder and response to lithium treatment. Am J Psychiat 148:1237-1239

Fava M, Rosenbaum JF, McGrath PJ, Stewart JW, Amsterdam JD, Quitkin FM (1994): Lithium and tricyclic augmentation of fluoxetine treatment for resistant major depression: A double-blind, controlled study. Am J Psychiat 155:1372-1374

Fawcett J, Clark DC, Aagesen CA, Pisani VD, Tilkin JM, Sellers D, McGuire M, Gibbons RD (1987): A double-blind, placebo-controlled trial of lithium carbonate therapy for alcoholism. Arch Gen Psychiat 44:248-256

Fieve RR, Dunner DL, Kumbarachi T, Stallone F (1975): Lithium carbonate in affective disorders. IV. A double-blind study of prophylaxis unipolar recurrent depression. Arch Gen Psychiat 32:1541-1544

Fieve RR, Dunner DL, Kumbaraci T, Stallone F (1976): Lithium carbonate prophylaxis of depression in three subtypes in primary affective disorder. Pharmakopsychiat Neuro-Psychopharmakol 9:100-107

Folks DG, King LD, Dowdy SB, Petrie WM, Jack RA, Kooman JC, Swenson BR, Edwards P (1982): Carbamazepine treatment of affectively disordered inpatients. Am J Psychiat 139(1):115-117

Freeman TW, Clothier JL, Passaglia P, Lesem MD, Swann AC (1992): A double-blind comparison of valproate and lithium in the treatment of acute mania. Am J Psychiat 149:108-111

Fogelson DL, Jacobson S, Sternbach H (1991): A retrospective study of valproate in private psychiatric practice. Ann Clin Psychiat 3:315-320

Forstner U, Bohus M, Gebicke-Harter PJ, Baumer B, Berger M, van Calker D (1994): Decreased agonist-stimulated $\mathrm{Ca}^{2+}$ response in neutrophils from patients under chronic lithium therapy. Eur Arch Psychiat Clin Neurosci 243:240-243

Friedman E, Wang HY, Levinson D, Connell TA, Singh H (1993): Altered platelet protein kinase C activity in bipolar affective disorder, manic episode. Biolog Psychiat 33: 520-525

Garfinkel PE, Stancer HC, Persad E (1980): A comparison of haloperidol, lithium carbonate, and their combination in the treatment of mania. J Aff Dis 2:279-288

Garver DL, Hirschowitz J, Fleischman R, Djuric PE (1984): Lithium response and psychosis: A double-blind placebo-controlled study. Psychiat Res 12(1):S7-S8

Gaviria M, Flaherty J, Val E (1982): A comparison of bipolar patients with and without a borderline personality disorder. Psychiatric J Univ Ottawa 7:190-195

Geisler A, Schou M (1973): Lithium treatment of obsessivecompulsive neurosis: A double-blind therapeutic trial with negative result. Foreign Psychiat 2:90-94

Gershon S, Trautner EM (1956): The treatment of shock dependency by pharmacological agents. Med J Australia 12(7):S2-S12

Gershon S, Yuwiler A (1960): Lithium ion: A specific psychopharmacological approach to the treatment of mania. J Neuropsychiat 1:229-241

Gershon S (1970): Lithium in mania. Clin Pharmacol Therapeu 11:168-187

Gershon S, Soares JC (1997). Commentary: Current therapeutic profile of lithium. Arch Gen Psychiat 54:16-20

Glen AI, Johnson AL, Shepherd M (1984): Continuation therapy with lithium and amitriptyline in unipolar depressive illness: A randomized, double-blind, controlled trial. Psycholog Med 14:37-50

Goetzl U, Gruenberg F, Berkowit B (1977): Lithium carbonate in management of hyperactive aggressive behavior of mentally retarded. Comp Psychiat 18:599-606

Goodwin FK, Murphy DL, Dunner DL, Bunney WE Jr. (1972): Lithium response in unipolar versus bipolar depression. Am J Psychiat 129:44-47

Goodwin FK, Zis AP (1979): Lithium in the treatment of mania-Comparisons with neuroleptics. Arch Gen Psychiat 36:840-844

Goodwin FK, Jamison KR (1990): Manic-Depressive Illness. New York, Oxford University Press

Goodwin GM (1994): Recurrence of mania after lithium withdrawal-Implications for the use of lithium in the treatment of bipolar affective disorder. Brit J Psychiat 164:149-152

Goodwin GM (1995): Lithium revisited-A reply. Brit J Psychiat 167:573-574

Grof P, Alda M, Grof E, Fox D, Cameron P (1993): The challenge of predicting response to stabilizing lithium treat- 
ment. The importance of patient selection. Brit J Psychiat 21:16-19

Growe GA, Crayton JW, Klass DB, Evans H, Strizich M (1979): Lithium in chronic schizophrenia. Am J Psychiat 136:454-455

Guscott R, Taylor L (1994): Lithium prophylaxis in recurrent affective illness. Efficacy, effectiveness, and efficiency. Brit J Psychiat 164:741-746

Harrow M, Goldberg JF, Grossman LS, Meltzer HY (1990): Outcome in manic disorders: A naturalistic follow-up study. Arch Gen Psychiat 47:665-671

Hartigan GP (1963): The use of lithium salts in affective disorders. Brit J Psychiat 109:810-814

Hayes SG (1992): Long-term valproate prophylaxis in refractory affective disorders. Ann Clin Psychiat 4:55-63

Heninger GR, Charney DS, Sternberg DE (1983): Lithium carbonate augmentation of antidepressant treatment. An effective prescription for treatment-refractory depression. Arch Gen Psychiat 40:1335-1342

Himmelhoch JM, Mulla D, Neil JF, Detre TP, Kupfer DJ (1976): Incidence and significance of mixed affective states in a bipolar population. Arch Gen Psychiat 33:1062-1066

Himmelhoch JM, Thase MF, Mallinger AG, Houck P (1991): Tranylcypromine versus imipramine in anergic bipolar depression. Am J Psychiat 148:910-916

Hirschowitz J, Casper R, Garver DL, Chang S (1980): Lithium response in good prognosis schizophrenia. Am J Psychiat 137:916-920

Hirschowitz J, Zemlan FP, Garver DL (1982): Growth hormone levels and lithium ratios as predictors of success of lithium therapy in schizophrenia. Am J Psychiat 139:646-649

Horowitz HA (1975): The use of lithium in the treatment of the drug-induced psychotic reaction. Dis Nerv Syst 36: 159-163

Hullin RP, McDonald R, Allsopp MNE (1972): Prophylactic lithium in recurrent affective disorders. Lancet ii:10441046

Jeffries JJ, Lefebvre A (1973): Depression and mania associated with Kleine-Levin-Critchley syndrome. Can Psychiatric Ass J 18:439-444

Joffe RT, Singer W, Levitt AJ, MacDonald C (1993): A placebo-controlled comparison of lithium and triiodothyronine augmentation of tricyclic antidepressants in unipolar refractory depression. Arch Gen Psychiat 50: 387-393

Johnson G, Gershon S, Hekimian LJ (1968): Controlled evaluation of lithium and chlorpromazine in the treatment of manic states: An interim report. Comp Psychiat 9:563-573

Johnson G (1970): Differential response to lithium carbonate in manic depressive and schizo-affective disorders. Dis Nerv Syst, September:613-615

Johnson G, Gershon S, Burdock EI, Floyd A, Hekimian L (1971): Comparative effects of lithium and chlorpromazine in the treatment of acute manic states. Brit J Psychiat 119:267-276

Johnson G (1974): Antidepressant effect of lithium. Comp Psychiat 15:43-47

Judd LL, Huey LY (1984): Lithium antagonizes ethanol intoxication of alcoholics. Am J Psychiat 141:1517-1521
Kane JM, Quitkin FM, Rifkin A, Ramos-Lorenzi JR, Nayak DD, Howard A (1982): Lithium carbonate and imipramine in the prophylaxis of unipolar and bipolar II illness: A prospective, placebo-controlled comparison. Arch Gen Psychiat 39:1065-1069

Keck PE Jr, McElroy SL, Nemeroff CB (1992): Anticonvulsants in the treatment of bipolar disorder. J Neuropsychiatry Clin Neurosci 4:395-405

Keller MB, Lavori PW, Coryell W, Endicott J, Mueller TI (1993): Bipolar I: A five-year prospective follow-up. J Nervous Mental Dis 181:238-245

Kendell RE (1985): The diagnosis of mania. J Aff Dis 8:207-213

Khan MC, Wickham EA, Reed JV (1987): Lithium versus placebo in acute depression: A clinical trial. Int Clin Psychopharmacol 2:47-54

Kofman O, Belmaker RH (1993): Ziskind-Somerfeld Research Award 1993. Biochemical, behavioral, and clinical studies of the role of inositol in lithium treatment and depression. Biolog Psychiat 34:839-852

Krauthammer C, Klerman GL (1978): Secondary maniaManic syndromes associated with antecedent physical illness or drugs. Arch Gen Psychiat 35:1333-1339

Kutcher SP, Marton P, Korenblum M (1990): Adolescent bipolar illness and personality disorder. J Am Acad Child Adoles Psychiat 29:355-358

Lambert PA, Carraz G, Borselli S, Carrel MS (1966): Action neuropsychotrope d'un nouvel anti-épileptique: le dépamide. Ann M Psychol 1:707-710

Lambert PA (1984): Acute and prophylactic therapies of patients with affective disorders using valpromide (dipropylacetamide). In Emrich HM, Okuma T, Muller AA (eds), Anticonvulsants in Affective Disorders. Amsterdam, Excerpta Medica, pp 33-44

Lejoyeux M, Ades J (1993): Evaluation of lithium treatment in alcoholism. Alcohol Alcoholism 28:273-279

Lerer B (1985): Studies on the role of brain cholinergic systems in the therapeutic mechanisms and adverse effects of ECT and lithium. Biolog Psychiat 20:20-40

Lerer B, Moore N, Meyendorff E, Cho SR, Gershon S (1987): Carbamazepine versus lithium in mania: A doubleblind study. J Clin Psychiat 48:89-93

Linder J, Fyro B, Pettersson U, Werner S (1989): Acute antidepressant effect of lithium is associated with fluctuation of calcium and magnesium in plasma. A doubleblind study on the antidepressant effect of lithium and clomipramine. Acta Psychiat Scand 80:27-36

Lingjaerde $\mathrm{O}$, Edlund AH, Gormsen CA, Gottfries CG, Haugstad A, Hermann IL, Hollnagel P, Makimattilla A, Rasmussen KE, Remvig J, Robak OH (1974): The effects of lithium carbonate in combination with tricyclic antidepressants in endogenous depression. A double-blind, multicenter trial. Acta Psychiat Scand 50:233-242

Lusznat RM, Murphy DP, Nunn CM (1988): Carbamazepine vs. lithium in the treatment and prophylaxis of mania. Brit J Psychiat 153:198-204

Maj M (1984): Effectiveness of lithium prophylaxis in schizoaffective psychosis: Application of a polydiagnostic approach. Acta Psychiat Scand 70:228-234

Maj M (1988): Lithium prophylaxis of schizoaffective disorders: A prospective study. J Aff Dis 14:129-135 
Maj M, Pirozzi R, Starace F (1989): Previous pattern of course of the illness as a predictor of response to lithium prophylaxis in bipolar patients. J Aff Dis 17:237-241

Maj M, Pirozzi R, Kemali D (1991): Long-term outcome of lithium prophylaxis in bipolar patients. Arch Gen Psychiat 48:772

Mander AJ (1986): Is there a lithium withdrawal syndrome? Brit J Psychiat 149:498-501

Mander AJ, Loudon JB (1988): Rapid recurrence of mania following abrupt discontinuation of lithium. Lancet 2:15-17

Manji HK, Lenox RH (1994): Long-term action of lithium: A role for transcriptional and postranscriptional factors regulated by protein kinase C. Synapse 16:11-28

Manji HK, Potter WZ, Lenox RH (1995): Signal transduction pathways. Molecular targets for lithium's action. Arch Gen Psychiat 52:531-543

Marini JI, Sheard MH (1977): Antiaggressive effect of lithium ion in man. Acta Psychiat Scand 55:269-286

Mattsson B, von Schoultz B (1974): A comparison between lithium, placebo, and a diuretic in premenstrual tension. Acta Psychiat Scand 255:75-84

McCoy L, Votolato NA, Schwarzkopf SB, Nasrallah HA (1993): Clinical correlates of valproate augmentation in refractory bipolar disorder. Ann Clin Psychiat 5:29-33

McDougle CJ, Price LH, Goodman WK, Charney DS, Heninger GR (1991): A controlled trial of lithium augmentation in fluvoxamine-refractory obsessive-compulsive disorder: Lack of efficacy. J Clin Psychopharmacol 11:175-184

McElroy SL, Keck PE Jr, Pope HG Jr (1987): Sodium valproate: its use in primary psychiatric disorders. J Clin Psychopharmacol 7:16-24

McElroy SL, Keck PE, Pope HG, Hudson JI (1988): Valproate in the treatment of rapid cycling bipolar disorder. J Clin Psychopharmacol 8:275-278

McElroy SL, Keck PE Jr, Pope HG Jr, Hudson JI, Faedda GL, Swann AC (1992a): Clinical and research implications of the diagnosis of dysphoric or mixed mania or hypomania. Am J Psychiat 149:1633-1644

McElroy SL, Keck PE Jr, Pope HG Jr, Hudson JI (1992b): Valproate in the treatment of bipolar disorder: Literature review and clinical guidelines. J Clin Psychopharmacol $12: 42 S-52 S$

Mehta DB (1976): Lithium and affective disorders associated with organic brain impairment. Am J Psychiat 133:236

Mendels J, Secunda SK, Dyson WL (1972): A controlled study of the antidepressant effect of lithium carbonate. Arch Gen Psychiat 26:154-157

Mendels J (1979): Lithium in the treatment of depression. Am J Psychiat 133:373-378

Mendlewicz J, Stallone F (1975): Genetic factors and lithium response in manic-depressive illness. Mod Prob Pharmacopsychiat 10:23-29

Merry J, Reynolds CM, Bailey J, Coppen A (1976): Prophylactic treatment of alcoholism by lithium carbonate. A controlled study. Lancet 1:481-482

Miller FT, Libman H (1979): Lithium carbonate in the treatment of schizophrenia and schizo-affective disorder: Review and hypothesis. Biol Psychiat 14:705-710
Moskowitz IA (1980): Lithium and lady luck: Use of lithium carbonate in compulsive gambling. NY State J Med 80: 785-788

Moncrieff J (1995): Lithium revisited-A re-examination of the placebo-controlled trials of lithium prophylaxis in manic-depressive disorder. Brit J Psychiat 167:569-574

Naylor GJ, Donald JM, Le Poidevin D, Reid AH (1974): A double-blind trial of long-term lithium therapy in mental defectives. Brit J Psychiat 124:52-57

Neppe VM (1988): Carbamazepine in nonresponsive psychosis. J Clin Psychiat 49:22-28

Noack CH, Trautner EM (1951): Lithium treatment of maniacal psychosis. Med J Australia 18:219-222

Noyes R Jr, Dempsey M, Blum A, Cavanaugh GL (1974): Lithium treatment of depression. Comp Psychiat 15:187-193

O'Connell RA, Mayo JA, Flatow L, et al. (1991): Outcome of bipolar disorder on long-term treatment with lithium. Brit J Psychiat 159:123-129

Ogura C, Okuma T, Nakazawa K, et al. (1976): Treatment of periodic somnolence with lithium carbonate. Arch Neurol 33:143

Okuma T, Inanaga K, Otsuki S, et al. (1979): Comparison of the antimanic efficacy of carbamazepine and chlorpromazine: A double-blind controlled study. Psychopharmacology 66:211-217

Okuma T, Inanaga K, Otsuki S, et al. (1981): A preliminary double-blind study on the efficacy of carbamazepine in prophylaxis of manic-depressive illness. Psychopharmacology 73:95-96

Okuma T (1983): Therapeutic and prophylactic effects of carbamazepine in bipolar disorders. Psychiat Clin North Am 6:157-174

Okuma T, Yamashita I, Takahashi R, Itoh H, Otsuki S, Watanabe S, Sarai K, Hazama H, Inanaga K (1990): Comparison of the antimanic efficacy of carbamazepine and lithium carbonate by double-blind controlled study. Pharmacopsychiatry 23:143-150

Perris C (1978): Morbidity suppressive effect of lithium carbonate in cycloid psychosis. Arch Gen Psychiat 35:328-331

Peselow ED, Fieve RR, Difiglia C, et al. (1994): Lithium prophylaxis of bipolar illness. Brit J Psychiat 164:208-214

Petty F (1995): GABA and mood disorders: A brief review and hypothesis. J Aff Dis 34:275-281

Placidi GF, Lenzi A, Lazzerini F, Cassano GB, Akiskal HS (1986): The comparative efficacy and safety of carbamazepine versus lithium: A randomized, double-blind 3-year trial in 83 patients. J Clin Psychiat 47:490-494

Platman SR (1970): A comparison of lithium carbonate and chlorpromazine in mania. Am J Psychiat 127:351-353

Pond SM, Becker CE, Vandervoort R, Phillips M, Bowler RM, Peck CC (1981): An evaluation of the effects of lithium in the treatment of chronic alcoholism. I. Clinical results. Alcohol Clin Exper Res 5:247-251

Pope HG Jr, Lipinski JF, Cohen BM, Axelrod DT (1980): "Schizoaffective disorder": An invalid diagnosis? A comparison of carbamazepine disorder, schizophrenia, and affective disorder. Am J Psychiat 137:921-927

Post RM (1982): The use of the anticonvulsant carbamazepine in primary and secondary affective illness: Clinical and theoretical implications. Psycholog Med 12:701-704 
Post RM, Uhde TW, Ballenger JC, Squillace KM (1983): Prophylactic efficacy of carbamazepine in manic-depressive illness. Am J Psychiat 140:1602-1604

Post RM, Uhde TW, Roy-Byrne PP, Joffe RT (1987): Correlates of antimanic response to carbamazepine. Psychiat Res 21:71-83

Post RM, Altshuler LL, Ketter TA, Denicoff K, Weiss SR (1991): Antiepileptic drugs in affective illness. Clinical and theoretical implications. Adv Neurol 55:239-277

Post RM, Weiss SR, Chuang DM (1992): Mechanisms of action of anticonvulsants in affective disorders: comparisons with lithium. J Clin Psychopharmacol 12:23S-35S

Potter WZ, Bowden CL (1992): Valproate and mood disorders: Perspectives. Introduction. J Clin Psychopharmacol 12:2S-6S

Price LH, Henninger GR (1994): Lithium in the treatment of mood disorders. N Engl J Med 331:591-598

Prien RF, Caffey EM, Klett CJ (1972a): Comparison of lithium carbonate and chlorpromazine in the treatment of mania. Arch Gen Psychiat 26:146-153

Prien RF, Caffey EM Jr, Klett CJ (1972b): A comparison of lithium carbonate and chlorpromazine in the treatment of excited schizo-affectives. Report of the Veterans Administration and National Institute of Mental Health collaborative study group. Arch Gen Psychiat 27:182-189

Prien RF, Caffey EM, Klett CJ (1973a): Prophylactic efficacy of lithium carbonate in manic-depressive illness. Report of the Veterans Administration and National Institute of Mental Health Collaborative Study Group. Arch Gen Psychiat 28:337-341

Prien RF, Klett J, Caffey EM (1973b): Lithium carbonate and imipramine in prevention of affective episodes. A comparison in recurrent affective illness. Report of the Veterans Administration and National Institute of Mental Health Collaborative Study Group. Arch Gen Psychiat 29:420-425

Prien RF, Klett CJ, Caffey EM Jr (1974): Lithium prophylaxis in recurrent affective illness. Am J Psychiat 131:198-203

Prien RF, Kupfer DJ, Mansky PA, Small JG, Tuason VB, Voss CB, Johnson WE (1984): Drug therapy in the prevention of recurrences in unipolar and bipolar affective disorders. Report of the NIMH Collaborative Study Group comparing lithium carbonate, imipramine, and a lithium carbonate-imipramine combination. Arch Gen Psychiat 41:1096-1104

Prien RF, Himmelhoch JM, Kupfer DJ (1988a): Treatment of mixed mania. J Aff Dis 15:9-15

Prien RF (1988b): Maintenance treatment of depressive and manic states. In Georgotas A, Cancro R (eds), Depression and Mania. New York, Elsevier Science, pp 439-451

Prien RF, Gelenberg AJ (1989): Alternatives to lithium for preventive treatment of bipolar disorder. Am J Psychiat 146:840-848

Prien RF, Potter WZ (1990): NIMH workshop report on treatment of bipolar disorder. Psychopharmacol Bull 26:409427

Puzynski S, Klosiewicz L (1984): Valproic acid amide in the treatment of affective and schizoaffective disorders. J Aff Dis 6:115-121

Quitkin FM, Kane J, Rifkin A, Ramos-Lorenzi JR, Nayak DV (1981a): Prophylactic lithium carbonate with and with- out imipramine for bipolar 1 patients. A double-blind study. Arch Gen Psychiat 38:902-907

Quitkin FM, Kane JM, Rifkin A, Ramos-Lorenzi JR, Saraf K, Howard A, Klein D (1981b): Lithium and imipramine in the prophylaxis of unipolar and bipolar II depression: A prospective, placebo-controlled comparison. Psychopharmacol Bull 17:142-144

Ryback RS, Schwab RS (1971): Manic response to levodopa therapy: Report of a case. N Engl J Med 825:788-789.

Sarantidis D, Waters B (1981): Predictors of lithium prophylaxis effectiveness. Prog Neuropsychopharmacol Biol Psychiat 5:507-510

Sautter F, Garver D (1985): Familial differences in lithium responsive versus lithium nonresponsive psychoses. J Psychiat Res 19:1-8

Sautter FJ, McDermott BE, Garver DL (1990): A family study of lithium-responsive psychosis. J Aff Dis 20:63-69

Schexnayder LW, Hirschowitz J, Sautter FJ, Garver DL (1995): Predictors of response to lithium in patients with psychoses. Am J Psychiat 152:1511-1513

Schnur DB, Mukherjee S, Sackeim HA, Lee C, Roth SD (1992): Symptomatic predictors of ECT response in medicationnonresponsive manic patients. J Clin Psychiat 53:63-66

Schopf J, Baumann P, Lemarchand T, Rey M (1989): Treatment of endogenous depressions resistant to tricyclic antidepressants or related drugs by lithium addition. Results of a placebo-controlled double-blind study. Pharmacopsychiatry 22:183-187

Schou M (1963): Normothymotics, "Mood-normalizers"Are lithium and the imipramine drugs specific for affective disorders? Brit J Psychiat 109:803-809

Schou M (1979): Lithium in the treatment of other psychiatric and nonpsychiatric disorders. Arch Gen Psychiat 36: 856-859

Schou M (1991): Lithium and electroconvulsive therapy: Adversaries, competitors, allies? Acta Psychiat Scand 84:435-438

Scott ME, Mullaly RW (1981): Lithium therapy for cocaineinduced psychosis: A clinical perspective. Southern Med J 74:1475-1477

Secunda SK, Katz MM, Swann A, Koslow SH, Maas JW, Chuang S, Croughan J (1985): Mania diagnosis state measurement and prediction of treatment response. J Aff Dis 8(2):113-121

Shapiro DR, Quitkin FM, Fleiss JL (1989): Response to maintenance therapy in bipolar illness. Arch Gen Psychiat 46: 401-405

Sharma V, Persad E (1994): Pharmacotherapy of rapid cycling bipolar disorder: A review. Lithium 5:117-125

Sheard MH, Marini JL, Bridges CI, Wagner E (1976): The effect of lithium on impulsive aggressive behavior in man. Am J Psychiat 133:1409-1413

Shopsin B, Kim SS, Gershon S (1971): A controlled study of lithium versus chlorpromazine in acute schizophrenics. Brit J Psychiat 119:435-440

Shopsin B, Gershon S, Thompson H, Collins P (1975): Psychoactive drugs in mania. A controlled comparison of lithium carbonate, chlorpromazine, and haloperidol. Arch Gen Psychiat 32:34-42 
Siassi I (1982): Lithium treatment of impulsive behavior in children. J Clin Psychiat 43:482-484

Singer H, Cheng R, Schou M (1974): A controlled evaluation of lithium in the premenstrual tension syndrome. Brit J Psychiat 124:5-15

Sletten IW, Gershon S (1966): The premenstrual syndrome: A discussion of its pathophysiology and treatment with lithium ion. Comp Psychiat 7:197-206

Small JG, Small IF, Milstein V, Kellams JJ, Klapper MH (1985): Manic symptoms: An indication for bilateral ECT. Biolog Psychiat 20:125-134

Small JG, Klapper MH, Kellams JJ, Miller MJ, Milstein V, Sharpley PH, Small IF (1988): Electroconvulsive treatment compared with lithium in the management of manic states. Arch Gen Psychiat 45:727-732

Small JG, Klapper MH, Milstein V, Kellams JJ, Miller MJ, Marhenke JD, Small TF (1991): Carbamazepine compared with lithium in the treatment of mania. Arch Gen Psychiat 48:915-921

Smulevitch AB, Zavidovskaya GI, Igonin AL, Mikhailova NM (1974): The effectiveness of lithium in affective and schizoaffective psychosis. Brit J Psychiat 125:65-72

Solomon DA, Keitner GI, Miller IW, Shea MT, Keller MB (1995): Course of illness and maintenance treatments for patients with bipolar disorder. J Clin Psychiat 56:5-13

Spring G, Schweid D, Gray C, Steinberg J, Horwitz M (1970): A double-blind comparison of lithium and chlorpromazine in the treatment of manic states. Am J Psychiat 126:1306-1310

Stallone F, Shelley E. Mendlewicz J, Fieve RR (1973): The use of lithium in affective disorders. 3. A double-blind study of prophylaxis in bipolar illness. Am J Psychiat 130:1006-1010

Stein G, Bernadt M (1993): Lithium augmentation therapy in tricyclic-resistant depression. A controlled trial using lithium in low and normal doses. Brit J Psychiat 162: 634-640

Stoll AL, Banov M, Kolbrener M, Mayer PV, Tohen M, Strakowski SM, Castillo J, Suppes T, Cohen BM (1994): Neurologic factors predict a favorable valproate response in bipolar schizoaffective disorder. J Clin Psychopharmacol 14:311-313

Suppes T, Baldessarini RJ, Faedda GL, Tohen M (1991): Risk of recurrence following discontinuation of lithium treatment in bipolar disorder. Arch Gen Psychiat 48:1082-1088

Swann AC, Secunda SK, Katz MM, Koslow SH, Maas JW, Chang S, Robins E (1986): Lithium treatment of mania: Clinical characteristics, specificity of symptom change, and outcome. Psychiat Res 18:127-141

Takahashi R, Sakuma A, Itoh H, Kurihara M (1975): Comparison of efficacy of lithium carbonate and chlorpromazine in mania. Report of collaborative study group on treatment of mania in Japan. Arch Gen Psychiat 32: 1310-1318

Thomas J, Reddy B (1982): The treatment of mania. A retrospective evaluation of the effects of ECT, chlorpromazine, and lithium. J Aff Dis 4:85-92
Tohen M, Waternaux CM, Tsuang MT, Hunt AT (1990a): Four-year follow-up of twenty-four first-episode manic patients. J Aff Dis 19:79-86

Tohen M, Waternaux CM, Tsuang MT (1990b): A 4-year prospective follow-up of 75 patients utilizing survival analysis. Arch Gen Psychiat 47:1106-1111

Tupin J (1972): Lithium use in nonmanic depressive conditions. Comp Psychiat 13:209-214

Tyrer SP, Walsh A, Edwards DE, Berney TP, Stephens DA (1984): Factors associated with a good response to lithium in aggressive mentally handicapped subjects. Prog Neuro-Psychopharm Biol Psychiat 8:751-755

van Calker D, Forstner U, Bohus M, Gebicke-Harter P, Hecht H, Wark HJ, Berger M (1993): Increased sensitivity to agonist stimulation of the $\mathrm{Ca}^{2+}$ response in neutrophils of manic-depressive patients: Effect of lithium therapy. Neuropsychobiology 27:180-183

van Woert MH, Ambani LM, Weintraub MI (1971): Manic behavior and levodopa. N Engl J Med 285:1326

Vadnal R, Parthasarathy R (1995): Myo-inositol monophosphatase: Diverse effects of lithium, carbamazepine, and valproate. Neuropsychopharmacology 12:277-285

Watanabe S, Ishino H, Otsuki S (1974): Lithium and affective psychoses. Folia Psychiatrica et Neurologica Japonica 28:267-305

Watanabe S, Ishino H, Otsuki S (1975): Double-blind comparison of lithium carbonate and imipramine in treatment of depression. Arch Gen Psychiat 32:659-668

Watkins SE, Callender K, Thomas DR, Tidmarsh SF, Shaw DM (1987): The effect of carbamazepine and lithium on remission from affective illness. Brit J Psychiat 150:180 182

Wehr TA, Goodwin FK (1987): Can antidepressants cause mania and worsen the course of affective illness? Am J Psychiat 144:1403-1411

Will RG, Young JP, Thomas DJ (1988): Kleine-Levin syndrome: Report of two cases with onset of symptoms precipitated by head trauma. Brit J Psychiat 152:410-412

Wilson KCM, Scott M, Abou-Saleh M, Burns R, Copeland JRM (1995): Long-term effects of cognitive-behavioral therapy and lithium therapy on depression in the elderly. Brit J Psychiat 167:653-658

Worrall EP, Moody JP, Peet M, Dick P, Smith A, Chambers C, Adams M, Naylor GJ (1979): Controlled studies of the acute antidepressant effects of lithium. Brit J Psychiat 135:255-262

Wren JC, Kline NS, Cooper TB, Varga E, Canal O (1974): Evaluation of lithium therapy in chronic alcoholism. Clin Med 81:33-36

Young LD, Taylor I, Holmstrom V (1977): Lithium treatment of patients with affective illness associated with organic brain symptoms. Am J Psychiat 134:1405-1407

Zemlan FP, Hirschowitz J, Sautter FJ, Garver DL (1984a): Impact of lithium therapy on core psychotic symptoms of schizophrenia. Brit J Psychiat 144:64-69

Zemlan FP, Hirschowitz J, Garver DL (1984b): Mood-incongruent versus mood-congruent psychosis: Differential antipsychotic response to lithium therapy. Psychiat Res 11:317-328 